\title{
Carnival of the Monobloc covering, manipulating and masking of a chair
}

\author{
Tobias Linden* \\ University of Cologne, Germany
}

\begin{abstract}
Examining the concepts and ideas we have of objects and common goods such as the Monobloc chairs, or of mayor and globalized cultural events like the Art Biennale, they reveal their cultural and economic impact, especially because of their artistic and often political statements. In doing so, they expose a bit more about our contemporary society, our cultural heritage and sometimes give us advise or evoke ideas for the future. Furthermore, thinking about the artistic coverage, manipulating and masking of the Monobloc, these observations can show us our own attitudes towards everyday objects and common goods as well as helping us discover modernity. Finally, we can experience the Art Biennale in Venice more deeply, behind its vast different ranges of changing characteristics and faces throughout modern history.
\end{abstract}

Keywords: Monobloc, Art Biennale Venice, object art, concept art, artistic coverage.

Furniture tells stories. Stories about history, contemporary modern times and about the possible future of our everyday life as well. Regarding modern societies and our daily actions, for the most part we do our work and spend our free time sitting; sitting on chairs and couches, on the bed or, if there is no 
other possibility, sitting on the floor. To avoid that last circumstance, designers around the world have thought about making sitting comfortable throughout human history, about making it affordable and also suitable, regarding the appearance of seating furniture. Concentrating on the chair itself, this helpful device suiting individual designs in every room and environment we can think about, the Monobloc can be considered as the most successful chair around the globe. ${ }^{1}$ Rooted in European Renaissance, the understanding of the chair as holy throne turned with the development of the middle class into an everyday object in all kinds of design during the industrial revolution. Tracing the evolution of the chair to modern industrial times, even the materials and their manufacturing changed. Starting from individual craftsmanship with stone, wood and elaborate expensive materials, industrially advanced chairs are made by using steel, plastic and similar artificial substances.

In the 1960s the production of plastic chairs was rising, as is exemplified by Helmut Bätzner's 1966 chair “Bofinger”, which was produced from fiberglassreinforced polyester and casted in a single piece (Fig. 1). In times of economic recovery after the Second World War, the great advantage was that these kinds of mass-produced plastic chairs could be made in around four minutes. This

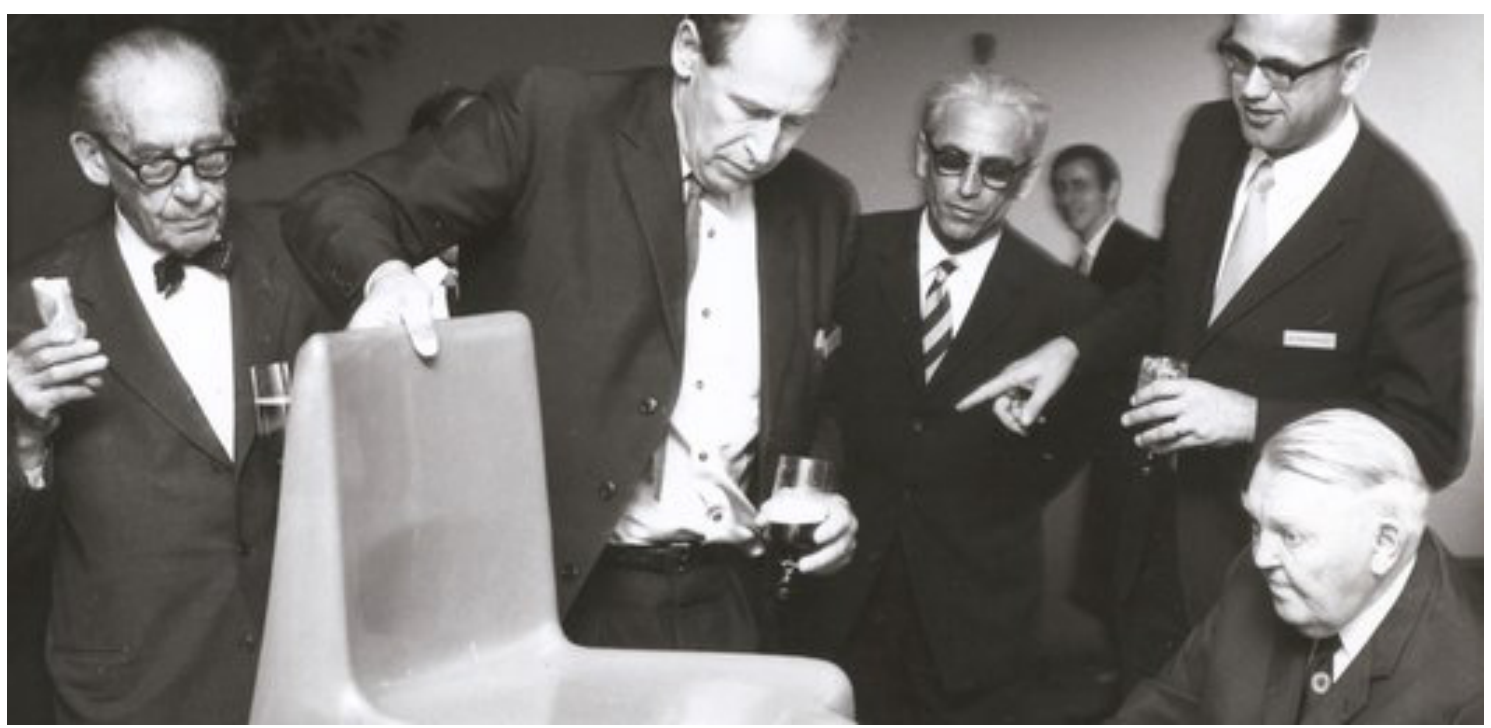

Fig. 1 - Philipp Rosenthal presents the finalist of the Rosenthal-Studio-Prize 1966 for the Bofinger Chair by Helmut Bätzner. Photo: Rosenthal. Source: Archive Beate Reichel. 
resulted in an enormous rise of production capacity and output. After the oil crisis in the 1970s, the world had to wait for the next development of plastic chairs until the 1990s, regarding Joe Colombo's and Vico Magistretti's ideas about affordable plastic seating furniture. The so-called Monobloc plastic chair was not sold as an individual artistic prototype or in thousands or millions, like the designs from Le Corbusier with his influence on the "De Stijl" group, the Bauhaus manufacturing, Thonet's Chairs or the Vienna coffee house chair before, but it was produced in billions. ${ }^{2}$

Under pressure, die-casting and at a temperature of 220 degree Celsius, the raw plastic became a globalized chair in rapid and cheap production. They are light-weighted, stackable and easy to clean. Therefore, they are perfect for outdoor occasions and for sidewalk cafés or restaurants and suitable for festivals. Here, the strong relation between the Monoblocs and tourists get obvious - and what can be considered more a hotspot of tourists than Venice? As commonly known, the greatest festival and public holiday in Venice is the Carnival. Since the late middle ages, the Carnevale di Venezia is the famous annual festival of celebrating the republic of Venice's victory over the historic enemy Aquileia in 1162. This tradition was forbidden after the annexation by Napoleon Bonaparte in 1797. Except for a few unsuccessful attempts in the $19^{\text {th }}$ century, the carnival, was not revived until Federico Fellini's movie "Casanova" in 1976. This movie triggered once again the desire for the carnival in Venice and reestablished the holiday. But how can the Carnival in Venice and the Monobloc chair be connected? Besides using the chairs as easy and cheap seating furniture in the streets during the festival days in the lagoon city, there is another, more correlative, aspect between them. Obviously, Carnival is the festival of masks and costumes - and the Monobloc itself often tends to cover and disguise its outward appearance. 


\section{Covering}

The Monobloc in its structure and appearance is a fully adaptative and not specified object - it provides the space for a lot of common and artistic interventions. I will start with the works of the swiss photographer Daniel Spehr who documented the touristic covering of the Monobloc in Chiang Mai, Thailand in 2005, a common method of hiding the plastic chair which will become clear by the photograph. After all, who does not know the all too often observed and experienced habit of tourists marking their pool territory with their towels in holiday resorts? Besides this custom usage of covering and the ironic reference to Christos' covering of environments and buildings, we can note a much more elaborate style to cover the Monobloc chair in Sweden.

In the Café of Tensta Konsthall (Fig. 2), a center for contemporary art in Stockholm, the white plastic chairs are luxuriously covered with black leather. This comfortable coating contrasts not only the flowery wall decoration in the tradition of art nouveau, but also reveals a whole different side of thinking about additional coverage. As has been shown, the Monobloc is rooted in café houses' traditional chair designs. Therefore, it is also consequential to pick up that thought and modulate it in a modern pattern.

The aspect of combining different materials does not only include the aspect of hiding the chair, it is a statement about negotiating the 'cheap' chair with high artistic and economic demanding as well, which itself leads to disturbing effects. Under his telling pseudonym, Lu Yii Wij Tong covered three Monoblocs in Louis Vuitton patterned leather in 2011 (Fig. 3). With this faked and not authorized design, the artist picked up on the vast amount of fake Louis Vuitton products and, in that reference, he communicates the power of fashion labels to convert cheap materials to luxurious and popular goods only with their prints as well. Just like all the artistic interventions of the Monoblocs, this imbalance and critique on labeled industries also springs from Dadaistic Pop-Art methods of the usage of "Readymades", 


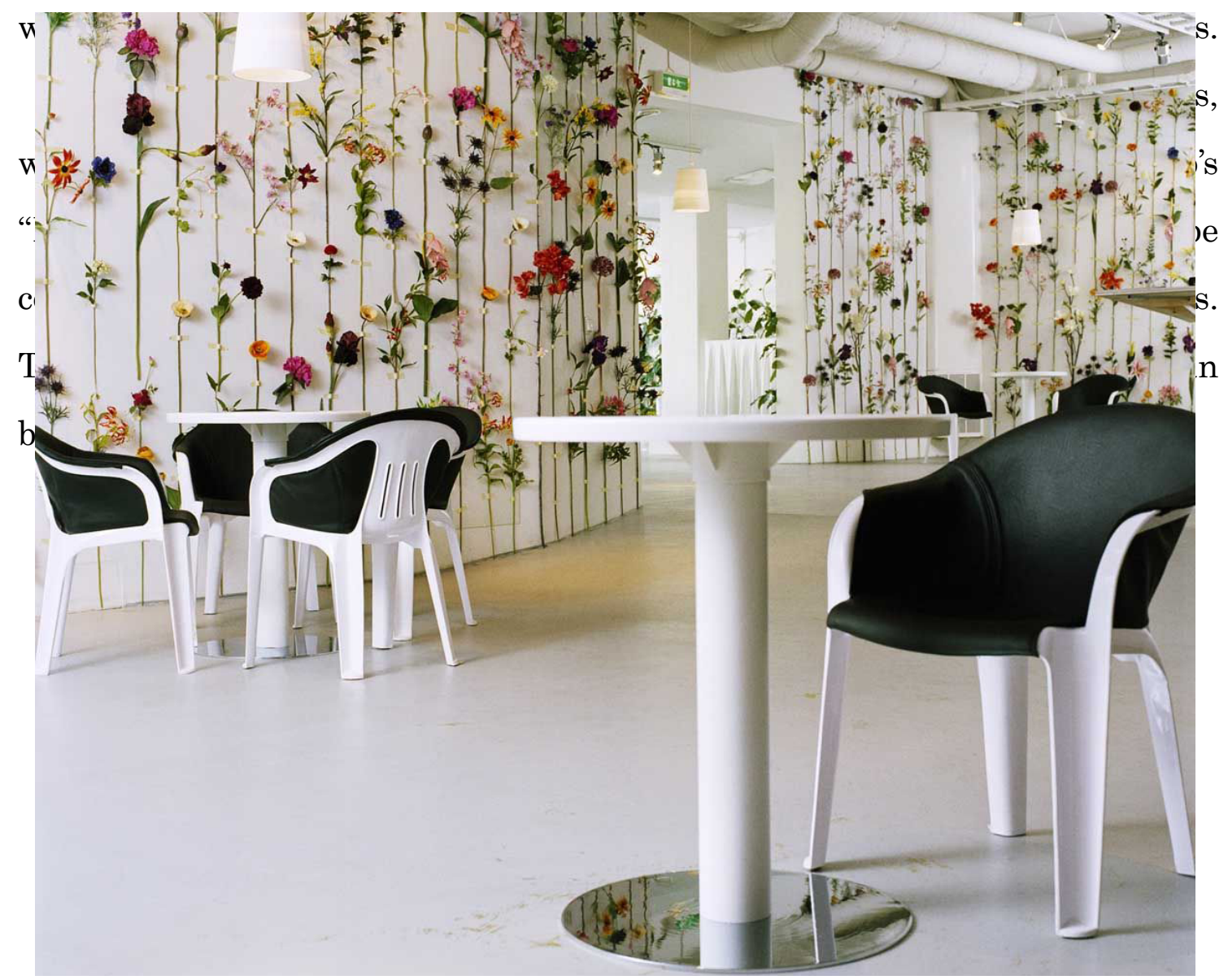

Fig. 2 - Café of Tensta Konsthall. Stockholm

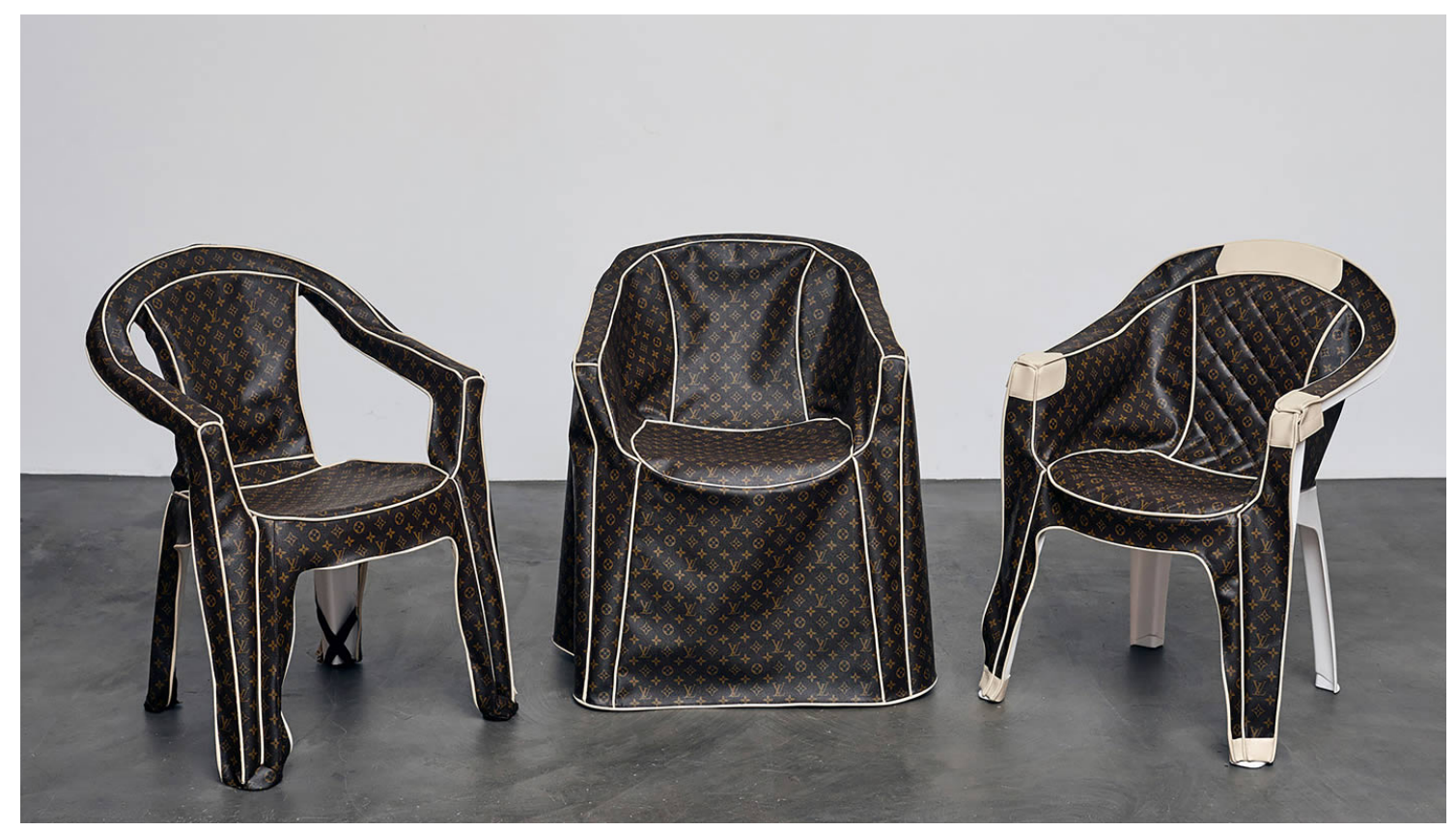

Fig. 3 - Lu Yii Wij Tong, Fake Louis-Vuitton Stuhl, 2011. Photo: Volker Albu 


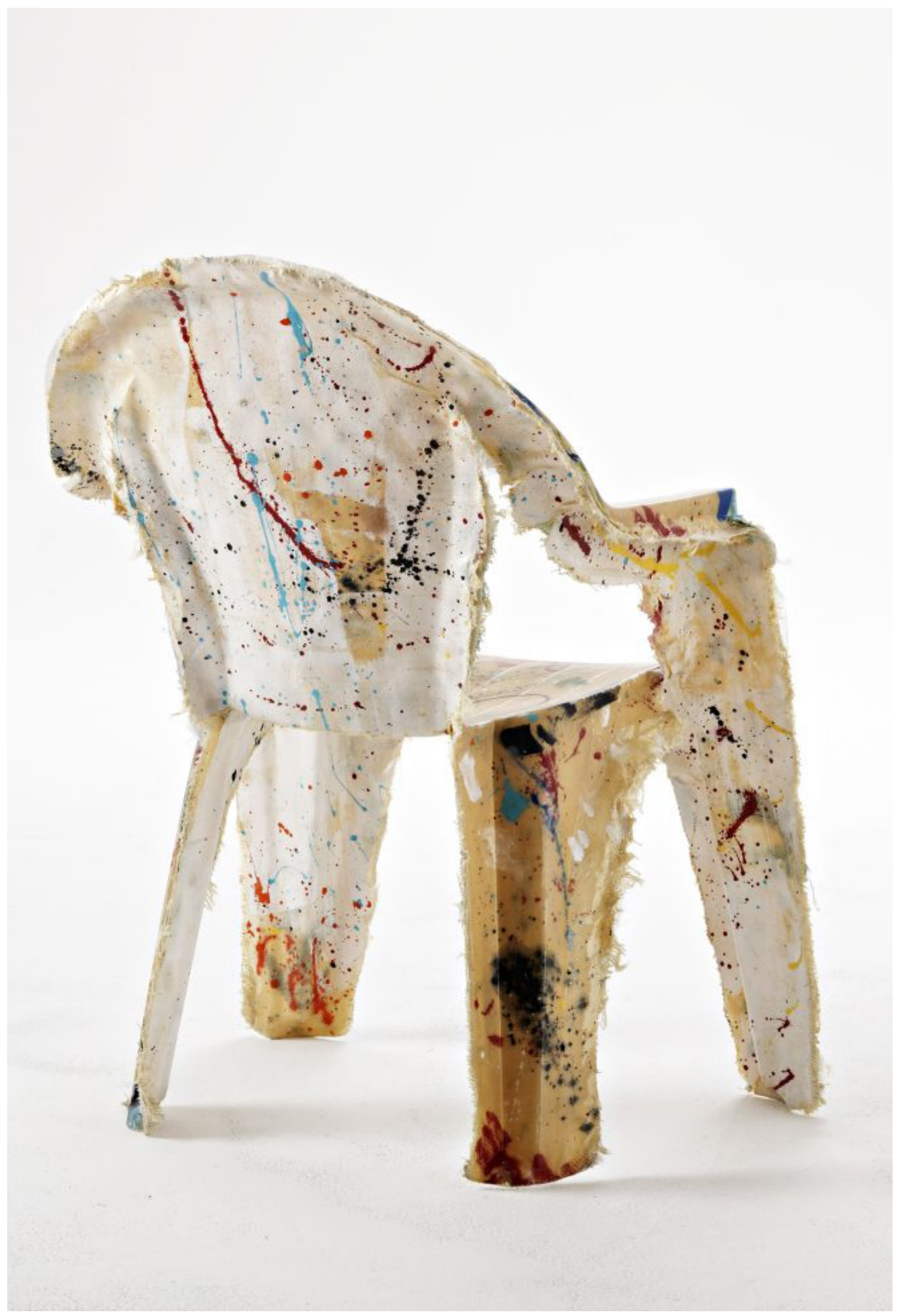

Fig. 4 - Rolf Sachs' "Dirty Thoughts" (2008-2009). Photo: https://rolfsachs.com/works/dirty-thoughts 
In this art work, the Swiss designer not only refers to the denotation of the dirty aspect of the Readymade implication itself, but also to the mostly easy cleaning of the plastic chair. Furthermore, he emphasizes the aesthetics of abstract expressionism of the mid $20^{\text {th }}$ century, as exemplified by the artistic approaches to the canvas of Jackson Pollock and Gerhard Richter. The tachistic expression of the human gesture leads back to the metaphorical costume of the Monobloc by highlighting the human body practice of hiding oneself behind a mask of habitus or a selected identity concept mirrored in the arts. The prototypical inversion of this principle is certainly the carnival and the adopting of a different outward experience and identity - as well as becoming anonymous and getting lost in the shuffle of Venice.

\section{Manipulation}

We can also call the temporary adoption of a different identity a willing manipulation of our self. But this can only happen if we are conscious about ourselves and conscious about what we are not. This reversed statement expressed through a costume can be observed in Martí Guixé's project "Respect Cheap Furniture" from 2009 as well (Fig. 5). He makes the bad reputation of the Monobloc and its 'identity' a subject of discussion. Guixé’s series of ten individual chairs reveals what comes to everybody's mind when getting in contact with the Monobloc: it is cheap, not valuable and, because of its mass production, a disposable object. His statement chairs also indicate an appreciation of cheaper goods and an awareness about disposable items in our lives - here, another relation to Venice and its preservation comes to the surface: The threat of environmental pollution and plastic littering in our contemporary debates.

Likewise, the Brazilian designers Humberto and Fernando Campana, known as the Campana Brothers, developed in their TransPlastic Collection the "Una Famiglia" in 2006, which combines the older coffee house style of wicker furniture with the modern styled plastic chair. This manipulation melds two 


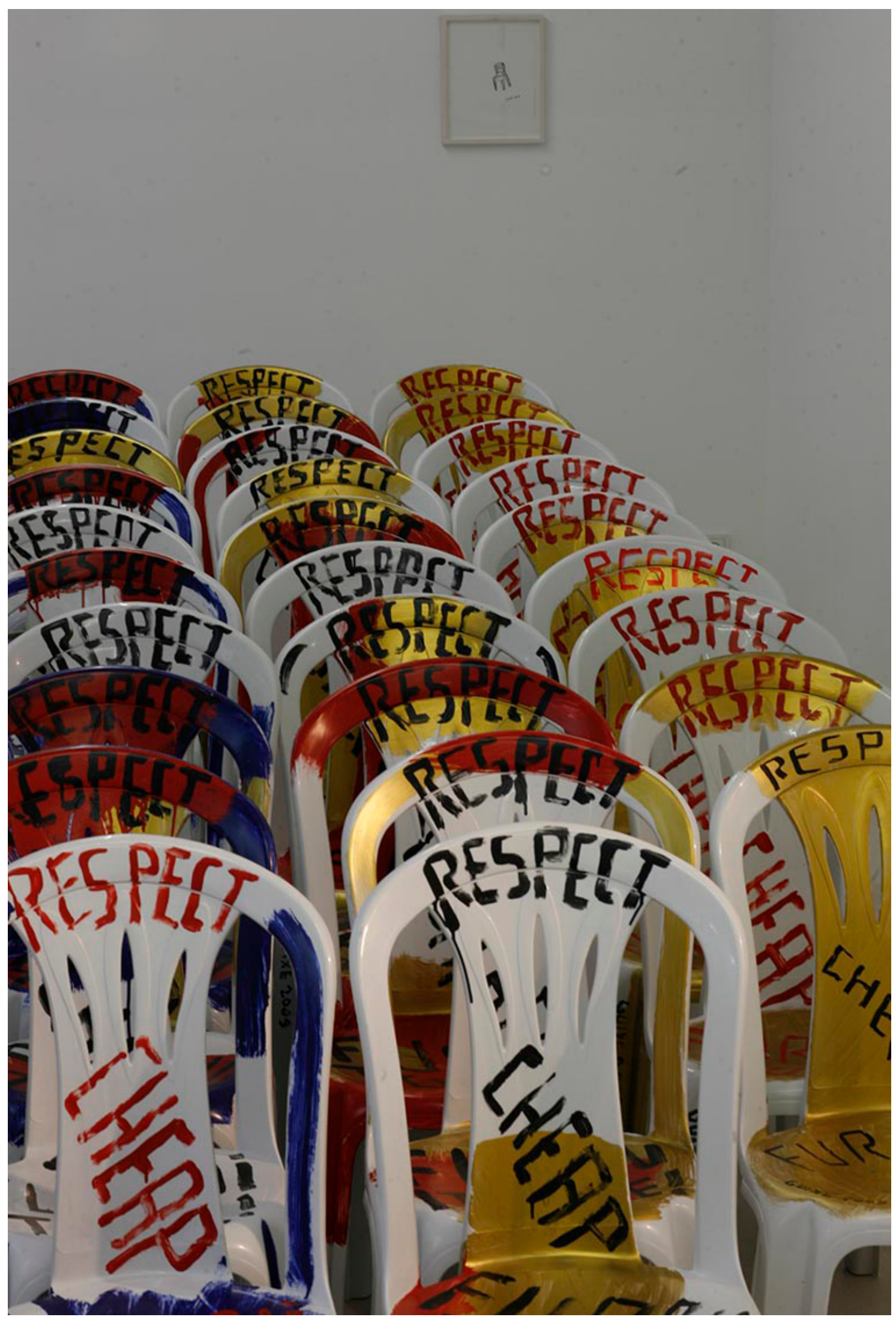

Fig. 5. Martí Guixé, Chairs \& Fireworks. Respect Cheap Furniture, 2009. https://www. martinrinderknecht.com/exhibitions/marti-guixe-chairs-fireworks/ 
or more Monoblocs together by using natural wicker. This artistic technique relates to sculpturing and concept art approaches by showing the connection between the monoblocs and their furniture-ancestors.

This artistic manipulation, which shows as well a relation to concept-lettering art approaches as well, finds its counterpart in Tina Roeders "White Billion Chairs" series from 2002 to 2009 (Fig. 6). Roeder illustrates the unimaginable number of Monobloc chairs by drilling thousands of individual holes into each chair. The artist states:

What is a monobloc chair worth? Can you add substances to an industrial product by taking away material, bit by bit, hole by hole, eventually rendering its structure, too fragile to support its traditional usage? Will we perceive the monobloc once we can see through it? [...] Are we close enough yet to look behind that perforated screen? ${ }^{3}$

The idea of looking behind the screen via a hole, via thousands of holes, can be considered on the one hand as making the chair itself invisible by getting closer to the core of what a Monobloc might represent in our culture. On the other, we are getting closer and closer to an object which is perforated for our sight. We do not have to perforate a screen metaphorically with our own eyes, the holes are already there. That is the symbolical multiplication of a voyeuristic act, which is a common theme in art and film making and media narration in general. This voyeuristic view also includes a restricted view, which produces the ambivalence of, first, control and power via voyeurism and, second, the experience of powerlessness due to a certain loss of perception. A typical Venetian carnival mask produces the same effect. The bearer of the mask is hiding their face, a powerful action, because you can walk through society incognito. The other aspect of control loss is also perceivable, because the mask certainly narrows the visual field. The metaphorical and philosophical question 


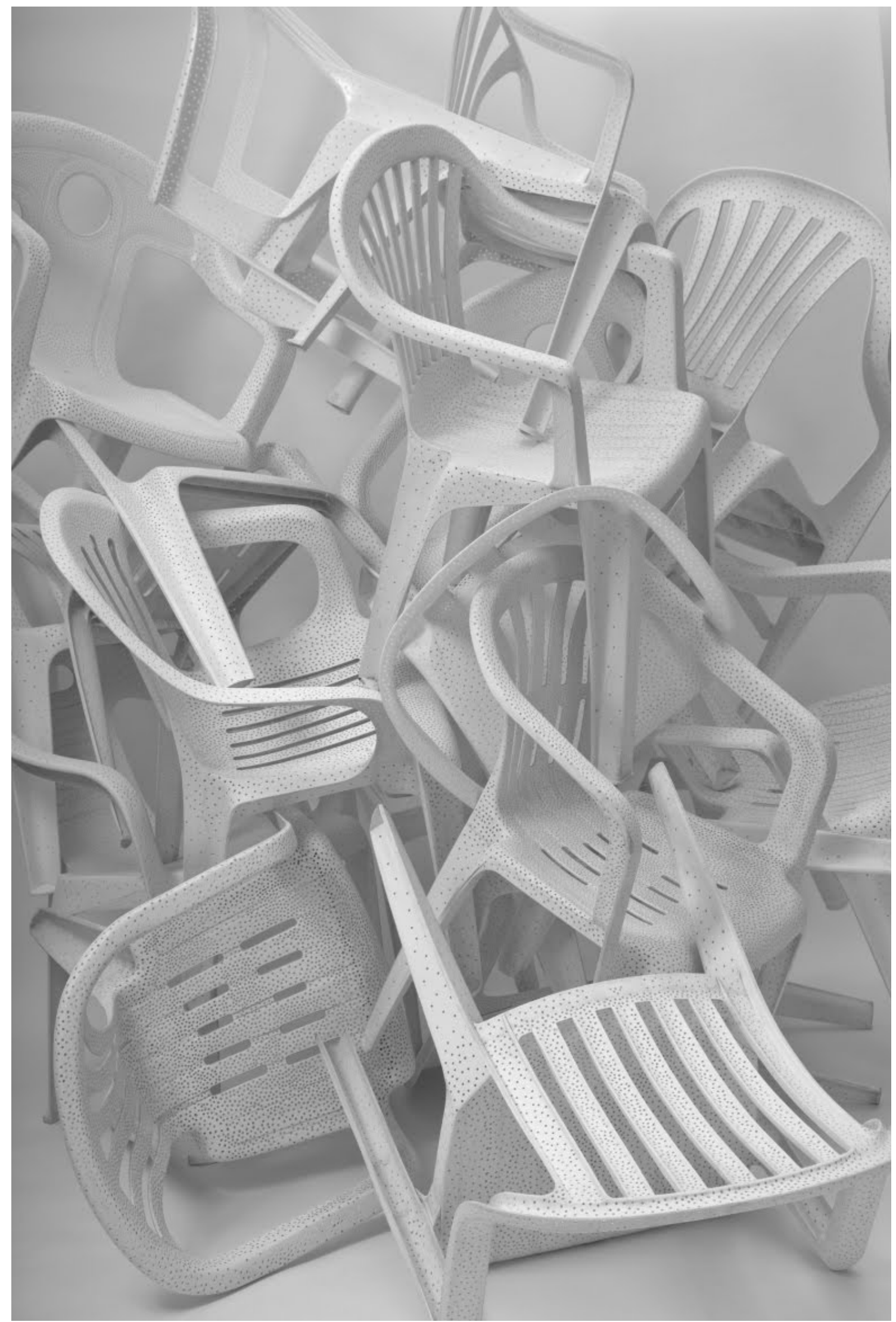

Fig. 6. Tina Roeder: White Billion Chairs, 2002-2009. http://tennthings.blogspot.com/2010/08/appeldesign-gallery.html 
Roeder asks is whether we are able to be voyeuristic enough and willing to see behind the outward shape or are we overwhelmed by the possibility and decisions presented by thousands of different starting points to get closer to the hidden concept of what the Monobloc is all about?

\section{Masking and conclusion}

While collecting all these relations between the artistic approaches to the Monobloc chair and Venice, I came across Carol Quint's sculptures "Utensil:1" and "Utensil:2" from 2001 (Fig. 7). The US-American sculptor has specialized on working with found material. In this case he used plastic knives, forks and spoons and arranged them on the Monobloc chairs. He sculptured heads with these disposable everyday objects, gave the Monoblocs a face of their own and hinted at the chair's former function as a throne. The faces themselves look masked, emphasize a melted person, and further illustrate the environmental plastic-related debates, which were mentioned before.

In these two artworks by Quint all the aspects come together, which I have named in this article: First, the connection of ground and surface material while covering the Monobloc and hiding its 'identity'; second, while manipulating the chair's outward shape, it gets a kind of costume which disguises it and it appears like the plastic melts the objects together to a new mold, a new mask for the Monobloc's identity. Therefore, here we have a metaphorically masked chair with a denotational masked face. All these points can be understood as allegory to the carnival in Venice and the cultural practice of becoming someone else, someone incognito for at least a few days a year.

Referring to German theater studies and Bertolt Brecht's epic theatre, masking ourselves on a stage, in public or simply in front of a mirror, reveals even more of our corporeality as it is intentionally hiding. ${ }^{4}$ Therefore, in conclusion, this topic points on a wider metaphorical level of the Art Biennale's history 


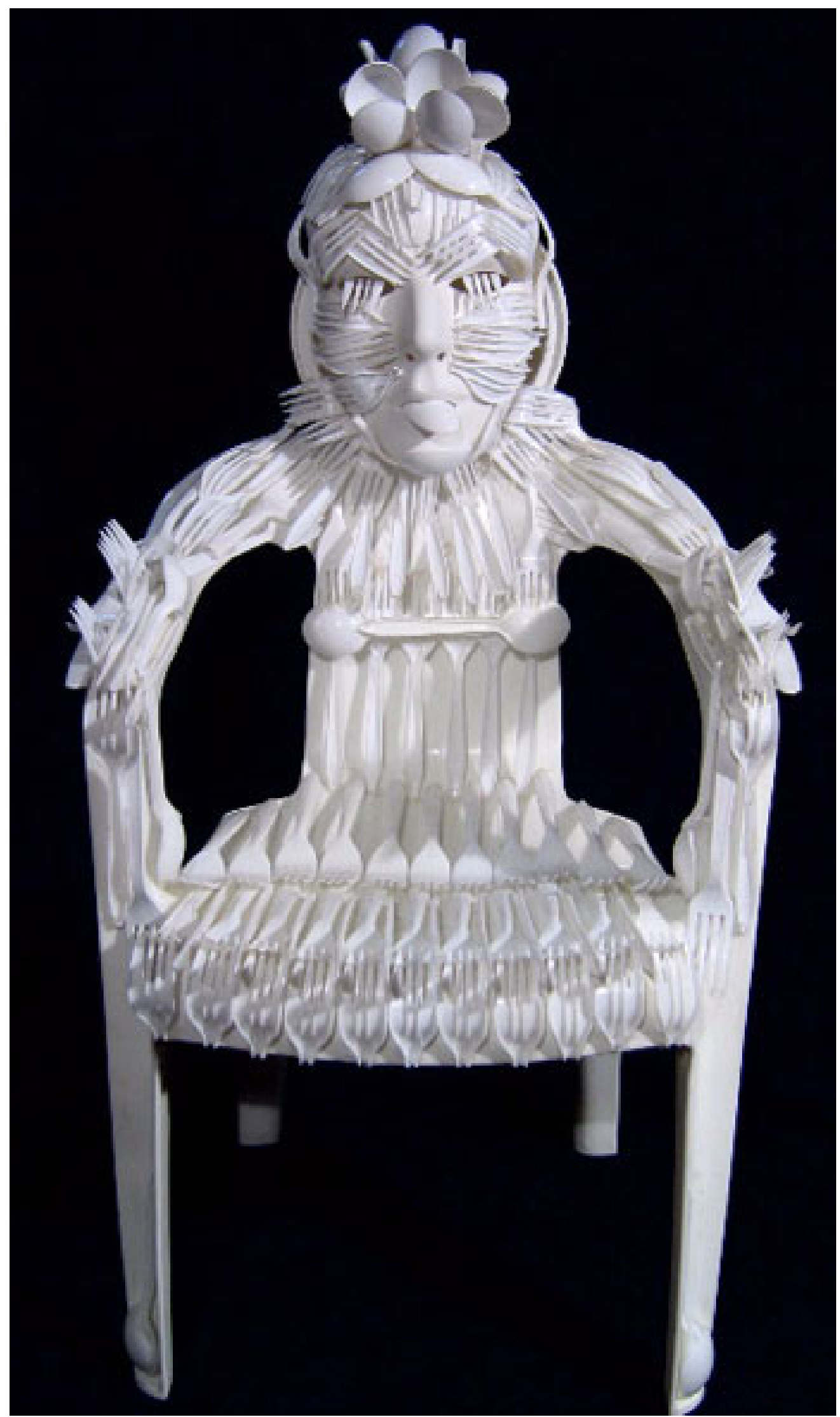

Fig. 7. - Carol Quint: Utensil:1, Sculptchair, plastic chair with plastic knives, forks and spoons, 2001. http://carolquint.com/art/gallery.php?CID $=1 \&$ start $=0 \& s=m \& I I D=25$ 
in Venice itself. Beginning in 1895, the "Espositione", curated by Italian and Venetian artists, experienced a lot of changes and modulations throughout the $20^{\text {th }}$ century until to today. The starting idea of exhibiting art without mayor gallery support at a kind of world exhibition has worn its masks and covering layers of characteristics and of provocations. ${ }^{5}$

The Art Biennale changed its outward appearances and exhibition concepts over time through adopting individual thoughts of its respective times: Giacomo Grosso's “Supremo convegno”, 1895, triumphs as Gustav Klimt's avantgarde presentations in the White Cube (1910), fascist and national political state attitudes (1934), Peggy Guggenheim's interventions to evoke the abstract and expressionist art stylistics (1948), ${ }^{6}$ and, finally, not to forget, the focus on the exhibition value of fine and concept arts in the beginning $21^{\text {th }}$ century with Maurizo Cattelans "La Nona Ora" at the biennale in 2001 were historic modulations of the idea of a world art exhibition in fanciful popular shapes of identities and mindsets. ${ }^{7}$

But nevertheless, these considerations lead me to the conclusion that examining the concepts and ideas we have of objects and common goods such as the Monobloc chairs, or of mayor and globalized cultural events like the Art Biennale, they reveal their cultural and economic impact, especially because of their artistic and often political statements. In doing so, they expose a bit more about our contemporary society, our cultural heritage and sometimes give us advise or evoke ideas for the future. Furthermore, thinking about the artistic modulation of the Monobloc, it can show us our own attitudes as well as helping us discover modernity. Finally, we can experience the Art Biennale in Venice more deeply, behind its vast different ranges of changing characteristics and faces throughout modern history.

That's because furniture tells stories. 


\section{NOTES}

1 Hajo Eickhoff, "Final Destination Plastic Chair. An Insight into the Culture of Sitting," in: The Infamous Chair. $220^{\circ} \mathrm{C}$ Virus Monobloc, ed. Andy Friedrichs, Kerstin Finger (Berlin: Gestalten, 2010), 6- 10.

2 Andrej Kupetz, "The efficient Form," in: The Infamous Chair. $220^{\circ} \mathrm{C}$ Virus Monobloc, ed. Andy Friedrichs, Kerstin Finger (Berlin: Gestalten, 2010), 10-13.

3 Tina Roeder, "White Billion Chairs (2002-2009)," in: The Infamous Chair. $220^{\circ} \mathrm{C}$ Virus Monobloc, ed. Andy Friedrichs, Kerstin Finger (Berlin: Gestalten, 2010), 42.

4 Bertolt Brecht, "A Short Organum for the Theatre 1949," in: Brecht on Theatre: The Development of an Aesthetic, ed. John Willett (London: Methuen, 1964), 179-205.

5 Enzo di Martino, The History of the Venice Biennale 1895-2005. Visual Arts, Architecture, Cinema, Dance, Music, Theater (Venice: Venezia Papiro Arte, 2005) 7-36, 40-53, 65-87.

6 Lawrence Alloway, The Venice Biennale 1895-1968. From Salon to Goldfish Blow (New York: New York Graphic Society, 1968), 38-42.

7 Robert Fleck, Die Biennale von Venedig. Eine Geschichte des 20. Jahrhunderts (Hamburg, Philo Fine Arts, 2009), 9-26.

Received: 2020-02-09

Revised: 2020-06-14

Accepted: 2020-06-29 